\title{
The History and Overview of Utah's Grazing Improvement Program
}

\author{
By Ashley T. Longmore and Troy Forrest
}

\section{On the Ground}

- Livestock numbers have been declining since the early 1930s but many of the same resource concerns are still present today.

- We must change the way we think about and manage livestock on our own in order to restore and maintain sustainable range resources.

- The Utah Department of Agriculture and Foods Grazing Improvement Program reaches across land ownership and jurisdictional boundaries to foster collaboration among private, federal, and state interests to implement sound grazing management practices that improve rangeland and watershed health.

- The Grazing Improvement Program focuses on three main principles:

- Time (the duration of grazing), timing (the season of use), frequency (how often the same plant is grazed), and intensity (amount of forage removed);

- Managing plant succession through grazing, mechanical, fire, chemical, and other means to enhance diversity and production (diversity = sustainability);

- Monitoring and adaptive management (you cannot manage what you do not measure).

Keywords: grazing, rangelands, management, Utah, livestock.

Rangelands 38(5):250-255

doi: 10.1016/j.rala.2016.08.007

(C) 2016 The Society for Range Management

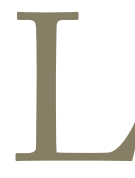

ivestock grazing in $\mathrm{Utah}^{\mathrm{i}}$ began in earnest with the arrival of the Mormon pioneers in 1847. By 1890, livestock numbers in the state were at an all-time high: the Agriculture Census recorded 3.5 million

The 70th Annual Society of Range Management Annual Meeting will be held in St. George, Utah 29 January-2 February 2017. This article highlights Utah range science and management. For more information on SRM Red Rock \& Rangelands 2017 see http://rangelands.org/srm17/. sheep and 500,000 cattle. ${ }^{1}$ Sheep production peaked around 1930, but since has declined by $89 \%{ }^{2}$ This decline came as a result of several factors, including low wool prices, less consumer preference for lamb, predator control problems, and difficulty finding labor. As the sheep industry declined, cattle took their place on the range: the number of beef cattle in Utah has doubled since 1920, making the industry one of the state's top sources of agricultural revenue. ${ }^{2}$

Heavy grazing from the late 1800s and early 1900s left Utah's rangelands depleted and watersheds damaged. Overgrazing left behind denuded soils that created additional problems including soil erosion and flooding. In 1932 the first record of vegetation composition changes on the Wasatch Front reported a move from perennial bunch grass systems to more shrub and annual grass. ${ }^{3}$

In 1905 the federal government moved its forest reserves to the jurisdiction of the renamed United States Forest Service (USFS) with a charge to curtail overgrazing and its harmful effects on watersheds. In 1912, the Great Basin Experiment Station was established in the Manti-LaSal National Forest near Ephraim. The experiment station helped implement research-based grazing models and produced long-term grazing records and studies, which advanced rangeland restoration science. In 1934 the federal Taylor Grazing Act established grazing permits that limited and regulated grazing on the rest of the public lands outside of the national forests. The Taylor Grazing Act marks the beginning of the science-based range management approach that we still see on our public lands today. ${ }^{2}$

Utah contains nearly 45 million acres of grazing lands. The federal government owns $73 \%$ of those lands, while the state owns $9 \%$, and the remaining $18 \%$ is private property. Grazing permits on federal lands are allotted in animal unit months (AUMs). An AUM is the amount of forage required to feed a mature, 1,000 pound cow (an animal unit) for 1 month. As the federal government owns nearly three-quarters of Utah's grazing lands, most grazing occurs on federal lands, but the amount of grazing allowed on those lands has been declining for decades. On Bureau of Land Management (BLM) lands, AUMs have declined from 2,749,000 in 1940 to less than 675,000 AUMs in 2009, a four-fold reduction. ${ }^{2}$ The AUMs on Forest Service grazing allotments have fallen from 2.7 million in the 1940 s to 614,000 in 2008. The significant 


\section{Change in Utah Federally Permitted}

AUMs 1940-2005

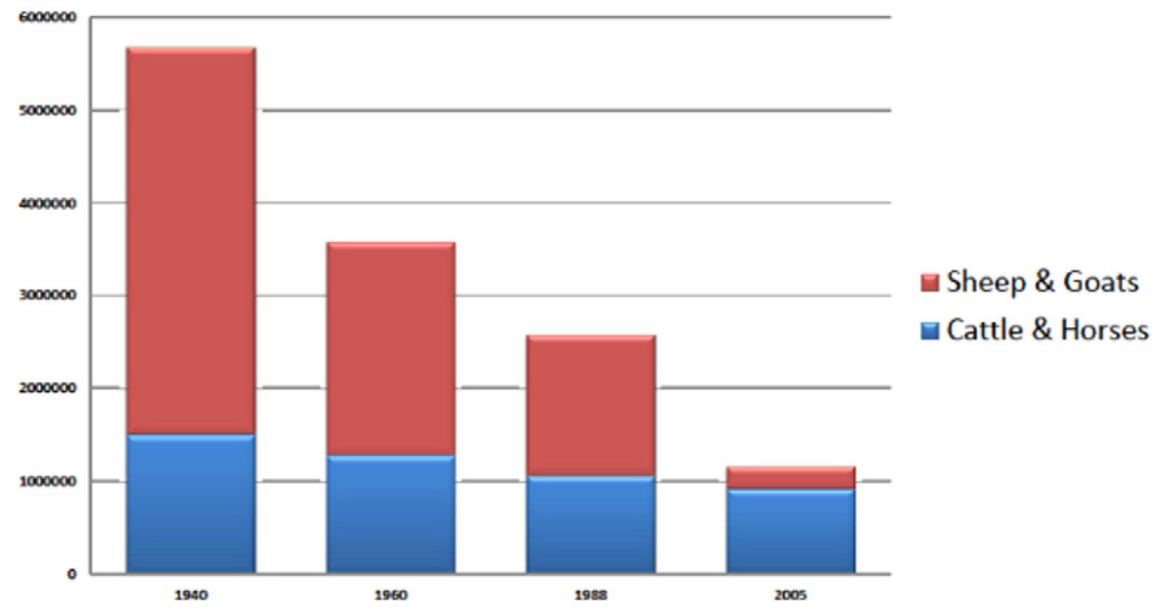

Figure 1. Changes in Federal livestock grazing AUMs permitted on BLM and USFS lands in Utah between 1940 and 2005.

decline in the number of AUMs available for grazing on public lands has increased grazing pressures on private lands (Fig. 1).

The grazing management techniques of the early 1900s reduced AUMs in an attempt to address the resource degradation concerns. Today, AUMs are still being reduced, but in many cases the same resource concerns remain. Often times a change in management practices is required to achieve the desired outcomes, rather than a reduction of AUMs permitted for the grazing allotments. This disconnect between the regulatory regime and good grazing practices motivated grazing experts in Utah to create a program that would promote and facilitate proper grazing techniques.

Considering Utah's changing demographics and the decline in public land grazing opportunity, the need for state-level representation for the livestock industry became a priority (Fig. 2).

History of Utahs Grazing Improvement Program

In 2006 the Utah Legislature passed HB 145, the Rangeland Improvement Act. ${ }^{4}$ The bill created the Grazing Improvement Program (GIP), along with a State Grazing Advisory Board and Regional Grazing Advisory Boards. The state and regional Grazing Advisory Boards give a voice to grassroots private and public grazing land managers and attracted strong support from the Utah Farm Bureau, Utah Cattlemen's Association, Utah Farmer's Union, Utah Woolgrowers Association, rural county commissioners, the Utah Association of Conservation Districts, and others.

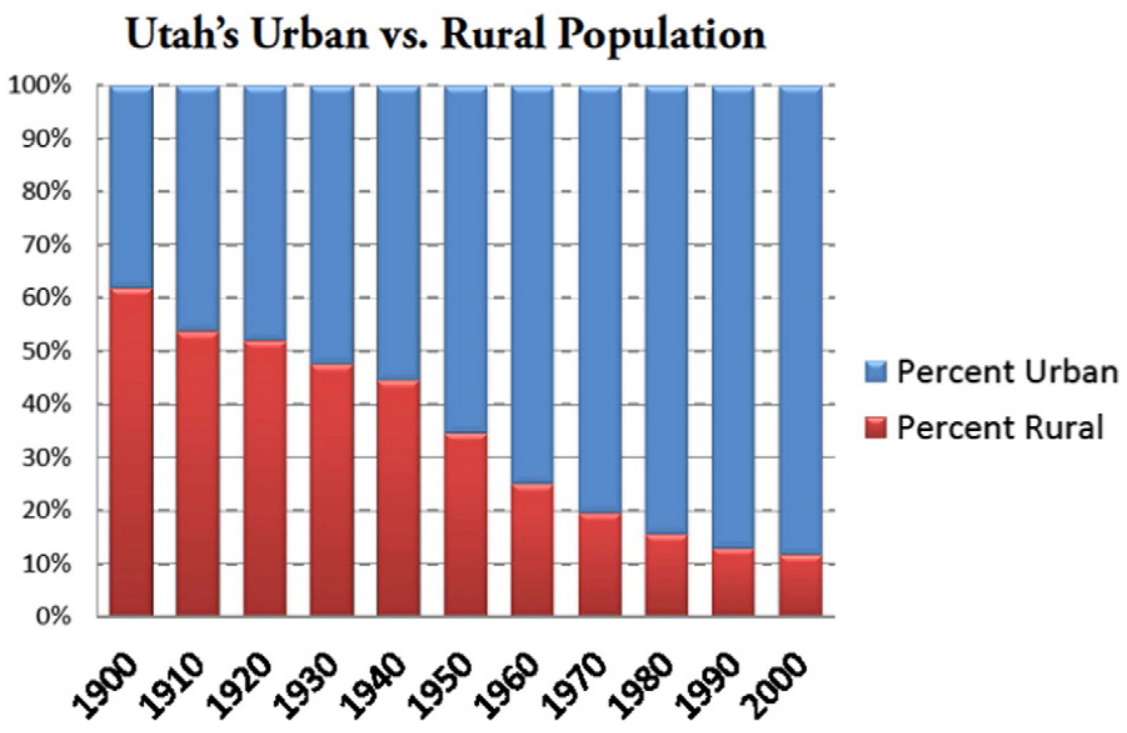

Figure 2. Changes in Utahs population demographics from 1900 to 2000. 
The GIP has four major components:

1. With input from grazing boards, Utah State University Extension and the Utah Department of Agriculture and Food, the GIP recommends positions on grazing issues for federal and state agencies;

2. Implements projects that rehabilitate Utah's natural resources, increase productivity, and protect the landscape;

3. Works with state and federal agencies to make land management decisions that are more reasonable, affordable, and effective in addressing grazing management and productive capacity of rangeland and watersheds; and

4. Partners with others to improve resource health and preserve livestock grazing on public lands.

For decades no one entity has been in a position to speak for, or represent, the interests of Utah's livestock industry during debates over rangeland issues. The GIP empowers Utah's grazing community to improve range conditions while protecting the environment. By preserving grazing, the program also contributes to the economic wellbeing of rural Utah, as the livestock grazing industry contributes more than $\$ 350$ million to Utah's economy and generates thousands of jobs.

Considering Utah's changing demographics and the decline in public land grazing opportunity, the need for state-level representation for the livestock industry has become a priority (Fig. 2).

The health of Utah's public and private rangeland resources depends on the ability to provide incentives to ranchers who have the greatest capability and opportunity to manage the land sustainably. If Utah is to improve and protect the health of its public and private rangelands and watersheds, the State will need to continue to provide guidance and incentives to achieve a high level of grazing management on a large scale. The scientifically-based principles to accomplish improved management are well known, but the technical guidance, social recognition, political will, and financial resources to bridge this gap are in short supply. Landowners and permittees are the 'boots on the ground' needed to achieve ecologic sustainability and create wealth from the land to be sustainable.

Well-managed livestock grazing, though poorly understood by the average citizen, is the most effective way to manage vegetation on a large scale to benefit watershed health and preserve wildlife habitat. Improving grazing management on Utah's public and private rangelands should be viewed as a long-term priority. A 1998 Government Accountability Office report, Forest Service Barriers to Generating Revenue or Reducing Costs, ${ }^{5}$ conveys the importance of economic sustainability on US Forest Service lands and the critical importance of multiple uses for the lands. The report provides good examples of a more "capitalistic" approach to public land management based on private land models. There is a powerful positive relationship between well-managed livestock grazing, healthy watersheds, and diverse and abundant wildlife populations.

The legislature funds the program with $\$ 1.6$ million annually that are matched using private and occasionally federal funds. Those funds are then used to implement improved grazing and rangeland management practices including water development (i.e., spring development, well drilling, installation of pipeline and troughs, installation of fencing, range seeding, brush and weed management, and juniper removal). These management tools improve livestock distribution, allow proper rest and recovery for plants, improve soil stability, increase wildlife habitat, and improve the overall vitality and health of rangelands. On the management side, the GIP focuses on three main principles, which are:

- Time (the duration of grazing), timing (the season of use), frequency (how often the same plant is grazed), and intensity (amount of forage removed).

- Managing plant succession through grazing, mechanical, fire, chemical, and other means can enhance diversity and production (diversity $=$ sustainability).

- Monitoring and adaptive management (you cannot manage what you cannot measure).

\section{Current Projects}

The GIP is working collaboratively with livestock producers and federal and state rangeland managers to put good grazing principles into action by working toward combining grazing allotments and providing funding for infrastructure. These improvements will allow for the successful implementation of large collaborative grazing management systems.

\section{Three Creeks in Rich County}

This project encompasses approximately 135,350 acres of BLM, Forest Service, and State Trust Lands, as well as 10,000 acres of private lands west of the town of Randolph, Utah. We proposed consolidating 10 existing livestock grazing allotments (5 USFS and 5 BLM) into one large management unit. The consolidation would include 30 pastures within the management unit to facilitate time-controlled grazing designed to maximize rest throughout the growing season. Infrastructure such as interior fencing, pipelines water troughs, and water wells with pumping plants are planned to facilitate this grazing plan. Management levels would be increased to move the cattle and sheep between the pastures to ensure progress over time to achieve rangeland health standards. Since 2011, the GIP has hosted many tours for influential groups and individuals of the proposed Three Creeks project. The project has been molded after the effective, Deseret Land and Livestock operation, located just 10 miles south of Three Creeks.

\section{Parker Mountain}

Parker Mountain is a 110,000-acre area comprised of BLM and School Institutional Trust Lands Administration (SITLA) lands located in Wayne and Piute counties in Central Utah. Improvements on the property include fencing to improve time, timing, and intensity of grazing, along with water projects to improve livestock distribution. Sagebrush has been thinned using Spike herbicide and other methods to try to improve habitat for sage grouse while also improving forage resources for cattle. There are 21 grazing permitees involved 


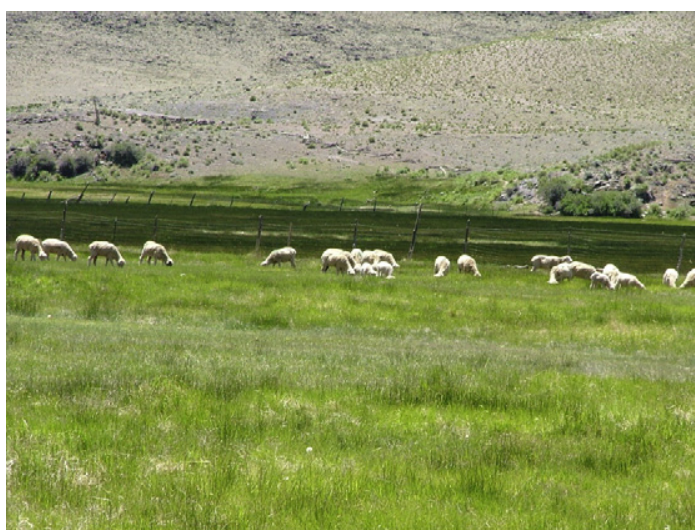

Image 1. Sheep grazing in Wayne County, Utah. Image by Troy Forrest.

on the project along with over 8,000 AUMs. Resources are improving and livestock performance is increasing.

\section{Monroe Mountain}

Monroe Mountain is a 140,000 acre area composed mostly of USFS lands located in Piute and Sevier counties in central Utah. The area is heavily used by elk, deer, and livestock, and aspen clones have been having difficulty regenerating. The plan is to treat large enough areas of aspen for regeneration to overcome the grazing pressure of the ungulate grazers. In preparation for this treatment, extensive water systems have been developed and a new grazing plan adopted that incorporates the principles of time, timing, and intensity to ensure that domestic grazers have a place to go during the treatments. It has also allowed for rested pastures on the mountain, which will improve resource health. This project includes 37 permit holders and over 10,000 AUMs.

\section{La Sal Sustainability Collaborative}

The La Sal Sustainability Collaborative (LSSC) is a 300,000 acre area composed of USFS, BLM, SITLA, and private lands located in San Juan County in southeastern Utah. The project's focus is to keep grazing sustainable while keeping native fish, plant, and animal populations stable at the same time. The collaborative is different from other

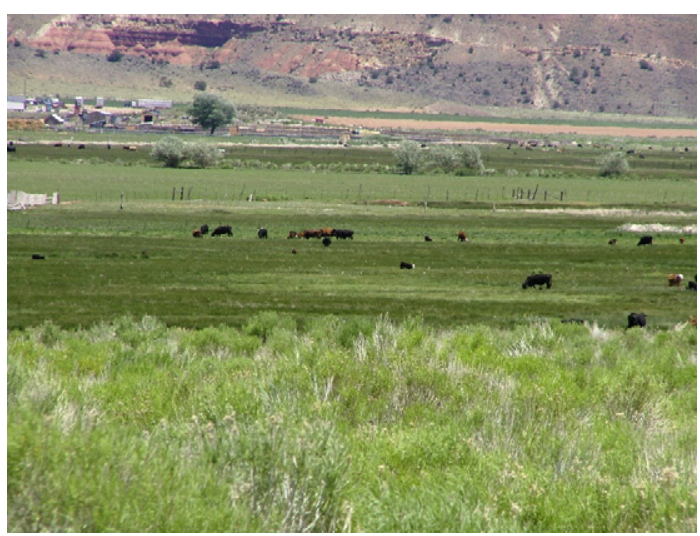

Image 2. Cattle grazing in Wayne County, Utah. Image by Troy Forrest.

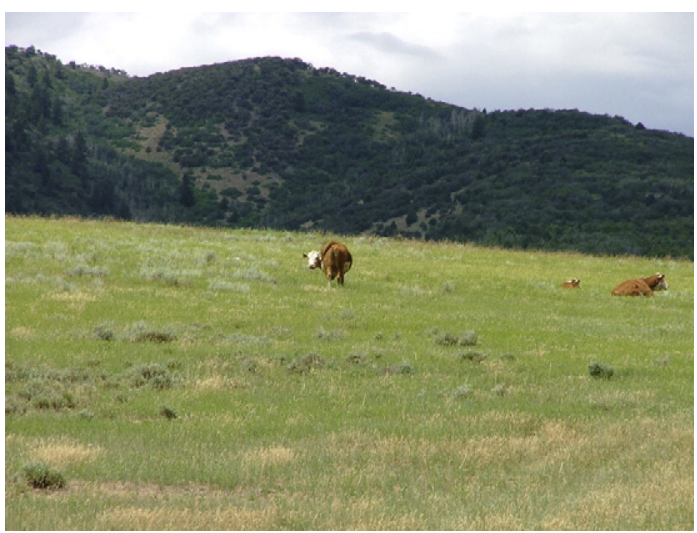

Image 3. Cattle grazing on 4 Mile Ranch in Cache Valley, Utah. Image by Troy Forrest.

projects in that it has defined sustainability in three different terms: economic sustainability, ecological sustainability, and social sustainability. The collaborative is in the process of defining each of these terms and coming up with ways to maintain all three types of sustainability. To date, they have looked at how better grazing management can play a role in improving all three types of sustainability and have been working on a new grazing plan. In addition, they have looked at processes and projects that can improve the sustainability of the landscape. The project includes a broad array of agencies and private and non-governmental interests that are striving to work together. There are two permit holders involved that run approximately 17,000 AUMs in the project area.

\section{Monitoring Successes}

Monitoring is a critical key to successfully manage rangelands, allow for adaptive management of grazing, and protect watersheds. Managers need to be able to tell the story of the rangeland, and monitoring is a critical part of that story. Monitoring provides a clear picture of what is on the ground and can, over time, show trends or changes in how vegetation is responding to whatever management practice is taking place on the range. The GIP sets aside 10\% of available funding to allow

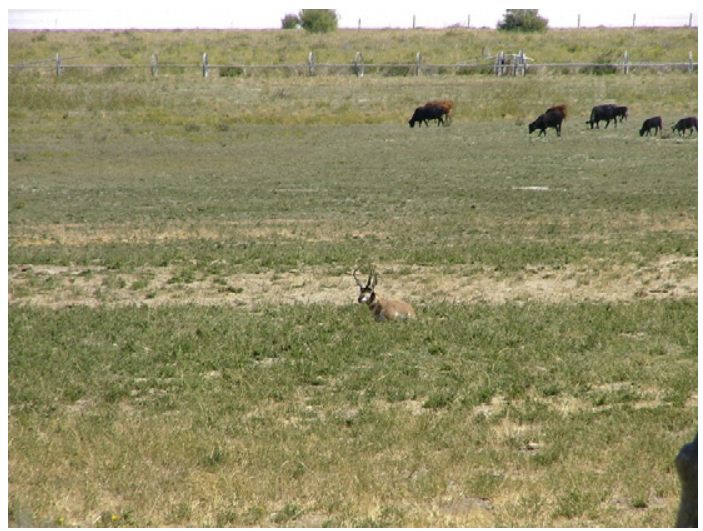

Image 4. Shared Rangelands, TL Bar Ranch, Box Elder, Utah. Image by Troy Forrest. 


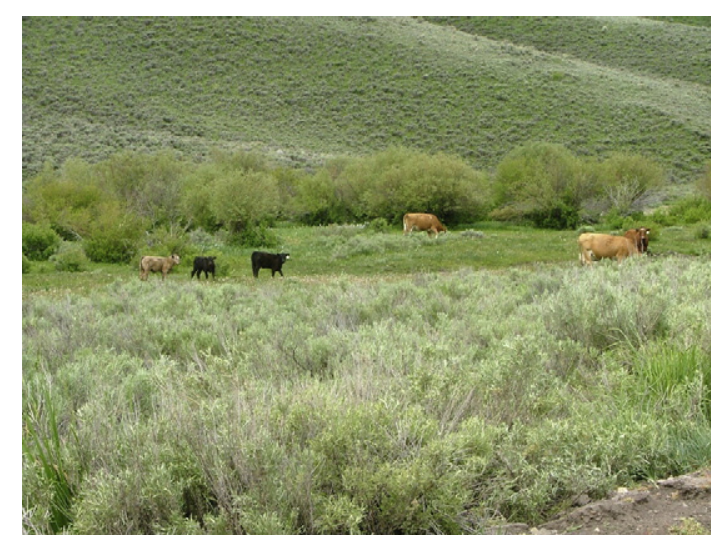

Image 5. Cattle grazing on Della Ranches in Box Elder County, Utah. Image by Troy Forrest.

staff to monitor projects by collecting data before implementation of the projects and then monitoring after implementation to help managers steer their management decisions in the best possible direction.

\section{Future of Grazing}

In the past the easiest and most politically expedient solution to grazing problems historically has been to reduce livestock numbers. In Utah this has resulted in a four-fold reduction in AUMs on federal land since 1960. However this often does not solve problems, especially if the problems on an allotment are related to livestock distribution. In addition to not solving the underlying ecological and environmental issues that the reduction hopes to solve, the reduction also creates economic hardship for the rancher who holds the permit and the rural communities that rely on ranching for their economic wellbeing. The UGIP assembled a technical committee made up of the best range professionals in the state of Utah, including USFS and BLM, and asked them to come up with a technical guidance for good grazing. One of the overarching ideas driving their recommendations is that "most rangelands are not overstocked, but they are often undermanaged."

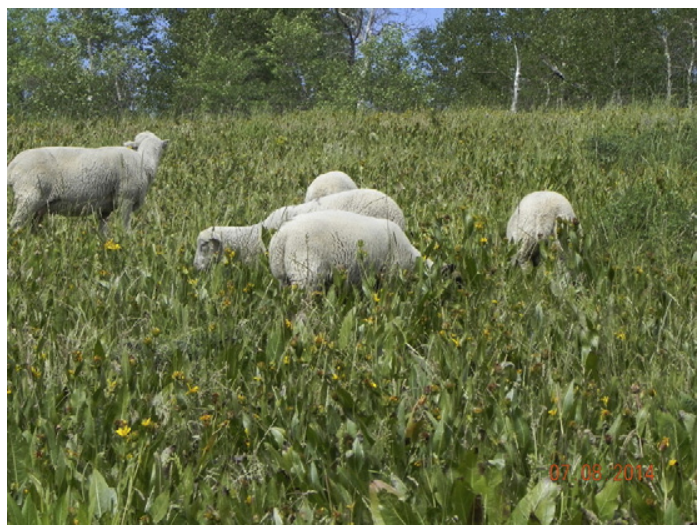

Image 6. Sheep grazing on Cache National Forest, Cache County, Utah. Image by Troy Forrest.

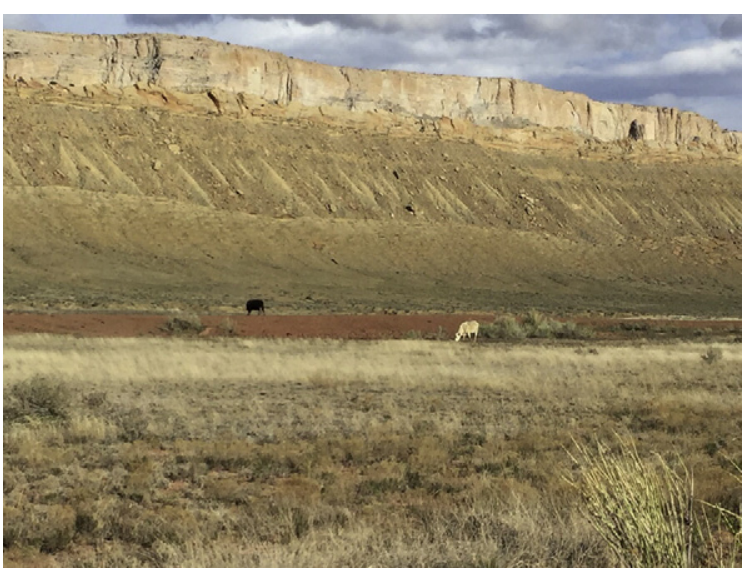

Image 7. Cattle grazing in Capitol Reef National Park, Utah. Image by Troy Forrest.

Cutting numbers makes ranching more economically difficult to sustain and still does not provide the ecological results that are being sought after. As we are taught by Range Management, "Proper [grazing management] schemes offer the range manager one of the most important tools in obtaining sustained productivity from rangelands. They must be properly designed and artfully applied to obtain the desired results...Moreover, and possibly more importantly, the rancher who adopts a grazing system is a more alert and observing manager." ${ }^{\prime 6}$ So the question becomes, how do we implement proper grazing management schemes? And how do we implement a science based grazing strategy on federal lands? Not to say that this has not been done; in other places and on various allotments, rest-rotation and deferred rotation management systems have been successfully implemented and range conditions have improved significantly. However we have only gone part of the way and we can do better. In Utah, the GIP hopes to lead the way to wider adoption of good range management practices that will change the downward trend of grazing on public land.

Grazing is an important management tool on rangelands. Often grazing is considered a detriment to the environment, but if rangeland managers are allowed to use the grazing principles of controlling the time, timing, frequency, and intensity of grazing, all of the resources associated with rangelands will be protected and multiple uses can coexist for future use of the amazing landscapes Utah has to offer. If livestock producers and rangeland managers can work cooperatively together, the future of grazing in Utah is bright.

\section{References}

1. United States Department of Agriculture-National Agriculture Statistics Service, et al. Available at: www.agcensus. usda.gov/Publications/Historical_Publications/1890/1890a_v501.pdf Accessed 15 May 2016.

2. Banner RE, Baldwin BD, \& McGinty EI, editors. 2009. Rangeland Resources of Utah. Logan, Utah, USA: Cooperative Extension Service, Utah State University in cooperation with the Utah Governor's Public Land Policy Coordination Office. 202 p. 
3. Utah Code Ann. § 4-20-1 et seq. Available at: http://le.utah.gov/ xcode/Title4/Chapter20/C4-20_1800010118000101.pdf. Accessed 15 May 2016.

4. Harrison, R.D., N.J. Chatterton, E.D. McArthur, D. Ogle, K.H. AsAY, AND B.L. WALDRON. 2003. Range plant development In Utah: A historical view. Rangelands 25:13-19.

5. United State General Accounting Office, 1998. Forest Service Barriers to Generating Revenue or Reducing Costs. 1998 Available at: www.gao.gov/assets/160/156106.pdf Accessed 15 May 2016.
6. Stoddart, L.A., A.D. Smith, and W. Thadis. 1975. Range Management. 3rd ed. New York, NY, USA: McGraw-Hill. 433 p.

Authors are Grazing Specialist, Utah Department of Agriculture and Food Grazing Improvement Program, Salt Lake City, UT 84116 (Longmore; ashleyhansen@utah.gov); and Program Manager, Utah Department of Agriculture and Food Grazing Improvement Program, Salt Lake City, UT 84116 (Forrest). 